\title{
A FINANCIAL IMPACT OF COVID-19 ON THE ECONOMY OF GEORGIA
}

\author{
MIRZA KHIDASHELI \\ Doctor of Business Administration \\ Professor \\ Kutaisi University, Georgia \\ mirza.khidasheli@unik.edu.ge
}

Abstract. Covid-19 pandemic have shaped new economic reality. Globalization shaped the new type of economic. Businesses are excessively depended on an international cooperation. After 11/4/2020 when WHO declared the global pandemic, developed states were trying to build own medical equipment factories, but it came up harder than it appeared first. Precisely no one knows a scale of the recession, because it depended on the healthcare issues, not on an economic itself. So, developed states already have announced unprecedented packages of fiscal and monetary stimulus.

Novel coronavirus outbreak creates economic threats for Georgian economic and financial stability too. But as everything, it has minimum two sides. Crises and shocks are a favorable time for rethinking everything again. The crisis can more precisely show the vulnerable areas and obtain a political support for changes and reforms. The permanent deficit of current accounts and trade balance is not new normal for Georgian economic, but the pandemic showed how it can increase rapidly by the tourism sector and the money transfers declining. Beside current account balance permanent deficit, a structure of the balance is another challenge. It is obvious that, economic development and improvement of trade balance are basic issues for sustainable economic, but without FDI it is a «mission impossible». The problem has complicated, because of last five-year FDI amounts are shrinking year to year. Another direction of pandemic interference is state budget. The budget revenues structural analyses showed increasing share of sovereign debt. Much more, GDP to sovereign debt ratio reached $40 \%$ in 2019. The currency devaluation and economic slowdown worsening this condition. So, we have less opportunities for debt in long run future. Another challenge of Georgian public finance is a structure of the budget expenses. A share of social costs and subsidies are consisting more than $1 / 3$ of the state budget and only $15 \%$ consists capital spending, which can really boost economy and promote employment in short run. Amid pandemic, banks credit portfolios also are under the risk, especially loans linked to tourism and development sectors. The pandemic shock needs two side response policy: fiscal stimulus in short run and structural reforms in long run. Creating monetary stimulus packages, Georgia is more restricted than developed economics and emerging markets. So, we need coherent structural reforms to accomplish comprehensive "small government" model. Social spending should be replaced by supporting economic growth and subsequent employment.

KEYWORDS: COVID-19, TRADE BALANCE, BUDGET DEFICIT, LIQUIDITY OF BANKING SECTOR, FINANCIAL STABILITY.

For citation: Khidasheli, M., (2020). The Impact of the Coronavirus on the Economy of Georgia. Globalization and Business, 10. 204-209. https://doi.org/10.35945/gb.2020.10.026

\section{INTRODUCTION}

The phenomenon of globalization has fundamentally changed the "working mechanism» of business and the economy. In today's world, neither of the developed and/ or developing economies are able not only to develop but also even to function properly without international trade. On March 11, 2020, the pandemic declared by the World Health Organization highlighted again the relevance of this assessment. It turned out that the majority of the world's political and economic centers are not even able to produce basic medical equipment independently. On March 23, 2020 , in view of the global pandemic and an epidemiological picture created in the country, the Government of Georgia decided to declare a state of emergency. This state of affairs substantially changes the economic landscape and creates challenges, the content of which is completely different from the traditional concepts of economic shocks.

In economic history, there have been crises causes of which were not economic in nature. For example, there is the economic crises caused by World War II and the collapse of the Communist system. However, these crises differ substantially from the coronomic crisis. In particular, after the end of World War II, cities and infrastructure were destroyed which required their restoration; at the same time, under the conditions of the coronomic crisis, there is no destruction there is only a lockdown of the functioning of the economy. (Papava, 2020:129) 


\section{The balance of payments}

The world entered the COVID-19 pandemic with persistent, pre-existing external imbalances. The crisis has caused a sharp reduction in trade and significant movements in exchange rates but limited reduction in global current account deficits and surpluses. The outlook remains highly uncertain as the risks of new waves of contagion, capital flow reversals, and a further decline in global trade still loom large on the horizon (Kaufman, Leigh, 2020).

In order to assess the economic shock caused by the pandemic, it is important to consider the parameters reflecting the relation of Georgia's economy to the rest of the world, i.e. the balance of payments. The year 2019 was the most successful in this respect in the last decade. The current account deficit was $\$ 0.9$ billion, representing a decline of $25 \%$ compared with the same figure in 2018 [\$ 1.2 billion]. The main reason for the positive result was the decrease in negative trade balance [2018 - $\$ 4.1$ billion] to $\$ 3.7$ billion. It should also be noted that in 2019 , merchandise exports [US $\$ 4.9$ billion] increased by $11 \%$ compared with the previous year, while imports [US $\$ 8.7$ billion] increased by only $2 \%$. No significant changes occurred in the balance of services, which decreased by $3 \%$ during this period and amounted to $\$ 2.1$ billion [see Figure 1].

The relationship between primary and secondary incomes remained unchanged. The negative balance of primary income amounted to $\$ 0.7$ billion, while the positive balance of secondary income amounted to $\$ 1.4$ billion. (National Bank of Georgia 2020)

As for the financial reporting, the main area of prime interest is foreign direct investment. This parameter has been steadily declining over the past 5 years, with the exception of 2017 [\$ 1.7 billion]. In 2019, this parameter increased by $4 \%$ compared to the previous year reaching $\$ 0.99$ billion.

The overall analytical picture of the current account, especially in view of the stability of the national currency, is as follows: the deficit in the goods trade and primary income balance is partially offset by the surplus balance of trade in services and secondary income. Pressure of the current account deficit on the national currency is relaxed by foreign direct investment. With regard to the latter, it should be noted that it has shown a clear downward trend.

The situation arising from the pandemic, as manifested in state border closures at the international level, as well as in immediate cessation of business activity at the local level, will undoubtedly reduce:

o Tourism revenue;

o Money remittances;

o Foreign direct investment.

In addition to the pandemic, the projected reduction in re-exports to Armenia in 2020 will also be added to the merchandise trade balance of Georgia, since Armenia joined the Eurasian Economic Union and automatically became a member of the Customs Union. In 2018, the exporst of motor vehicles to Armenia amounted to $\$ 253$ million, in the first 10 months of 2019 we already had $\$ 353$ million. In view of the anticipated sharp decline in exports of motor vehicles only to Armenia, Georgiass trade balance is in threat of further reduction by about GEL 1 billion.

In view of the above, the factors hindering the inevitable devaluation of the national currency may be:

o A sharp decline in trade, especially with respect to imports;

o International financial assistance and sovereign debt.

Following the declaration of the state of emergency, as expected, a sharp devaluation of the exchange rate began immediately. After an unequal decline, by March 26, national currency devaluation against the US dollar reaches a peak (\$1/GEL3.51), which remains almost unchanged until March 30, and begins to decline to 3.15. During this period, the National Bank of Georgia conducted three interventions

\section{FIG1. CURRENT ACCOUNTS 2012-2019 MLN USD}

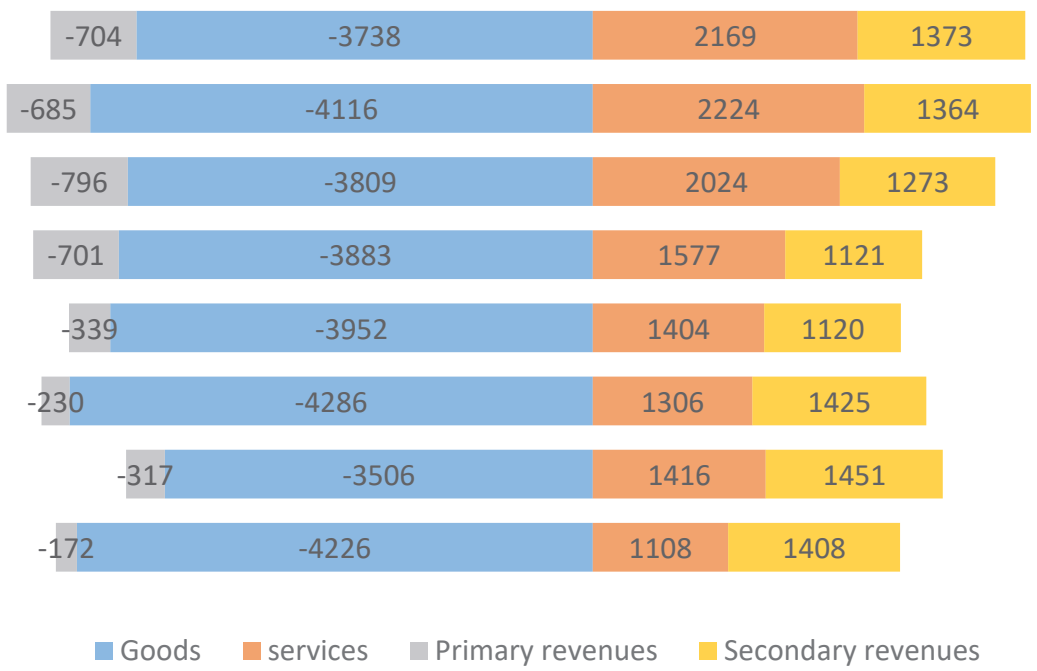

Source: Statistics of National Bank of Georgia 
FIG.2. BALANCE OF PAYMENTS ELEMENTS 2012-2019 MLN USD

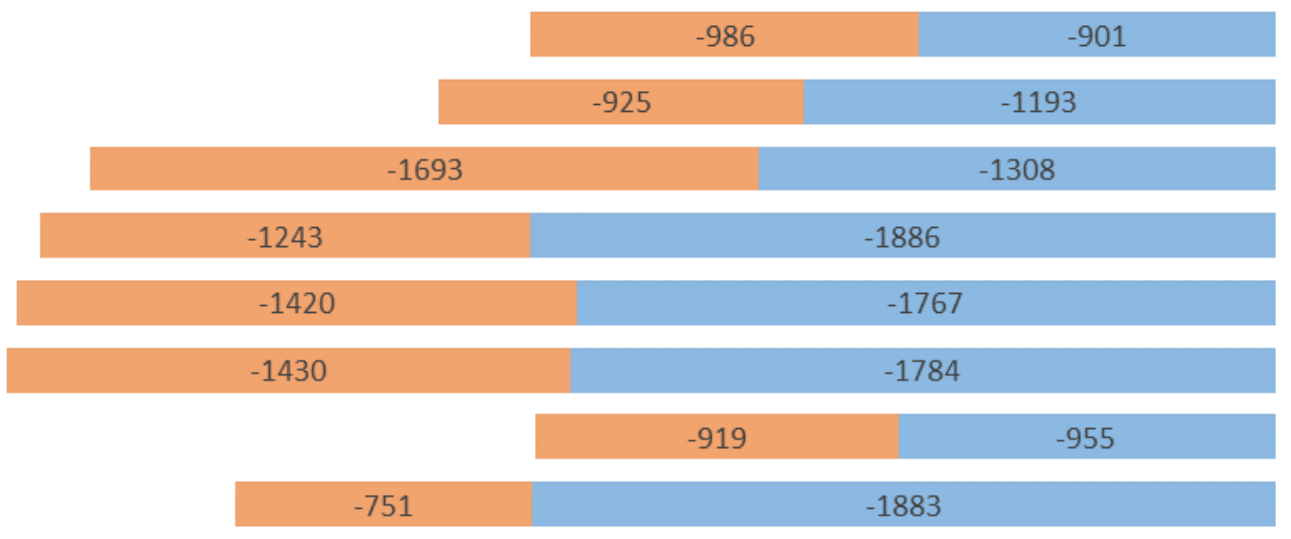

a Current accouts $\quad$ FDI

Source: Statistics of National Bank of Georgia

using the foreign exchange open market operations: on 13, 19 and 25 of March, respectively, the Bank sold \$20. \$40 and $\$ 40$ million at foreign currency auctions. It is noteworthy that the next day after the last intervention, the national currency continued to hold the peak value (xe.com, 2020).

Developments in the currency market revealed that the 3.51 mark recorded from 18 to 26 of March, along with fundamental factors, was the result of negative expectations. That is why there is a continuation of the negative trend of the exchange rate despite the interventions of the National Bank and the relative stabilization in the following days.

Despite the mitigated result recorded on March 18-26, the national currency has devaluated with respect to the US dollar by $12 \%$ between the beginning and end of March. Obviously, it is hard even to imagine any recurrence of shock resulting from to the pandemic declaration on March 11 and the establishment of state of emergency on March 23, but taking into consideration the dynamics of fundamental economic factors, if in the short run we fail to replace foreign direct investment, remittances and tourism revenues with alternative cash flows, in addition to a significant risk of recession, the issue of national currency exchange rate stability is at stake if short-term foreign direct investment, remittances and cash flow, stabilizing the national currency exchange rate will be one of the main challenges of 2020 .

\section{The fiscal deficit and liquidity of the banking sector}

The structural analysis of the balance of payments allowed us to see clearly some of the expected problems. With a view to obtaining an overall picture, it is necessary to consider the expected impact of the pandemic on the financial system.

Things will, however, be very different and dire for those who are deprived of their regular income while the coronacoma lasts. This group includes many workers and small businesses; it also includes state and local governments, which are required to balance their budgets but are seeing revenues collapse and expenses soar. (Krugman P 2020)
The planned state budget revenues for 2020 had increased by $11 \%$ compared to last year and amounted to GEL 14.6 billion. To assess the trends, it should be noted that with the growth of revenues, the share of liabilities in budget's structure is steadily increasing, which is $21 \%$ in its plan for 2020. In other words, in the state budget plan, 1 out of every $5 \mathrm{GEL}$ of revenue is received through a sovereign debt of 1 GEL. (State Budget 2020) The practice of supplementing a significant portion of budget funds from debt is undesirable to say the least. First of all, it emphasizes the quality and effectiveness of financial management. On the other hand, it diminishes the possibility of using tax incentives during the crisis. Sovereign debt is inevitable to offset the decline in tax revenues caused by the pandemic, however, as a result of the established debt practice, even in 2019, the ratio of Georgian government debt to nominal GDP exceeded $40 \%$ (Ministry of Finance of Georgia 2020). It should also be noted that the Organic Law of Georgia on Economic Freedom strictly defines the upper limit of sovereign debt, the ratio of which to nominal GDP should not exceed $60 \%$ (Organic Law of Georgia). It should be noted that $79 \%$ of sovereign debt accounts for external debt, while most of external debt is taken in foreign currency (Ministry of Finance of Georgia 2020). Accordingly, economic recession and devaluation of the national currency automatically increase the ratio of sovereign debt to GDP and diminish the possibility of balancing the budget deficit through government debt and the provision of fiscal incentives for the economy.

We have similar approaches and situation regarding the items of expenditure in the state budget. According to the planned state budget for 2020, 34\% of payments [GEL 4.8 billion] accounts for social security and subsidies. The budget spends GEL 1.9 billion on delivery of general-purpose public services (State budget for 2020).

GEL 1.6 billion is spent only on maintenance of public sector employees. Only $15 \%$ of budgetary payments [GEL 2.2 billion] are spent on increasing non-financial assets [See. Table 1.]. The table shows that the first priority of the state budget is social direction. In parallel with the 
Table 1

\begin{tabular}{|c|c|c|c|c|c|}
\hline \multicolumn{3}{|c|}{2020 State budget payments } & \multicolumn{3}{|c|}{2020 State budget, Functionaly } \\
\hline & $\mathrm{mln}$ Gel & $\%$ & & $\mathrm{mln}$ Gel & $\%$ \\
\hline Sallary & $1,575.9$ & $11 \%$ & General state service & $1,846.0$ & $14 \%$ \\
\hline Goods and services & $1,373.7$ & $10 \%$ & Defense & 987.0 & $7 \%$ \\
\hline Interest & 755.0 & $5 \%$ & Public order and safety & $1,215.6$ & $9 \%$ \\
\hline Subsidy & 516.5 & $4 \%$ & Economic activity & $2,222.2$ & $17 \%$ \\
\hline Grants & 726.1 & $5 \%$ & Environmental protection & 103.2 & $1 \%$ \\
\hline Social security & $4,294.8$ & $30 \%$ & Housing and communal services & 143.3 & $1 \%$ \\
\hline Others & $1,608.5$ & $11 \%$ & Health care & $1,134.5$ & $9 \%$ \\
\hline Increase in financial assets & 343.2 & $2 \%$ & Recreation, culture and religion & 352.2 & $3 \%$ \\
\hline Decrease in liabilities & $1,022.7$ & $7 \%$ & Education & $1,560.1$ & $12 \%$ \\
\hline Increase in non-financial assets & $2,221.4$ & $15 \%$ & Social protection & $3,512.2$ & $27 \%$ \\
\hline
\end{tabular}

improper structure of state budget revenues, we face significant threats to the optimal volumes of expenditures and payments. Although poverty remains a major challenge for Georgia, the increase in the share of social security in the budget can become one of the reasons for its strengthening instead of its elimination. Almost the axiomatic economic truth is that unemployment is defeated not by social security but by economic growth and employment. In Savings, and not social assistance packages or subsidies represent a much need source of economic growth. The economic slowdown caused by the pandemic, will worsen social background and will increase unemployment. Consequently, the state will have to assume even more social burden.

The pandemic is likely to bring about a rash of debt crises. Low interest rates combined with financial markets in advanced economies pushing loans and profligate borrowing in emerging market and developing economies have left several countries with more debt than they can service, given the magnitude of the pandemic-induced downturn. International creditors, especially private creditors, should know by now that you can't squeeze water out of stone. There will be a debt restructuring. The only question is whether it will be orderly or disorderly. (Stiglitz J, 2020)

As it was mentioned above, Economic consequences of the pandemic will take a toll on the banking sector. The largest share in the debt structure of the national economy is occupied by industry and trade, followed by construction industry, hotels and restaurants (see Figure 3)

Under conditions of full maintenance of the existing bed capacity, the average daily rate (ADR) will reduce by about $25 \%$, the average occupancy will reduce by $80 \%$, and the Revenue per available room (RevPAR) - by $85 \%$. Under these conditions, part of the hotels is expected to be temporarily out of the market until the demand returns significantly, which will increase operating indicators of the remaining hotels. In April, residential real estate sales dropped by $90 \%$. (TBC Capital, 2020).

The European Bank for Reconstruction and Development forecasts indicate that the Georgian economy will shrink by $5.5 \%$ in 2020 (EBRD, 2020). According to the initial data of

FIG 3. THE DEBT STRUCTURE OF THE NATIONAL ECONOMY $1 / 3 / 2020$

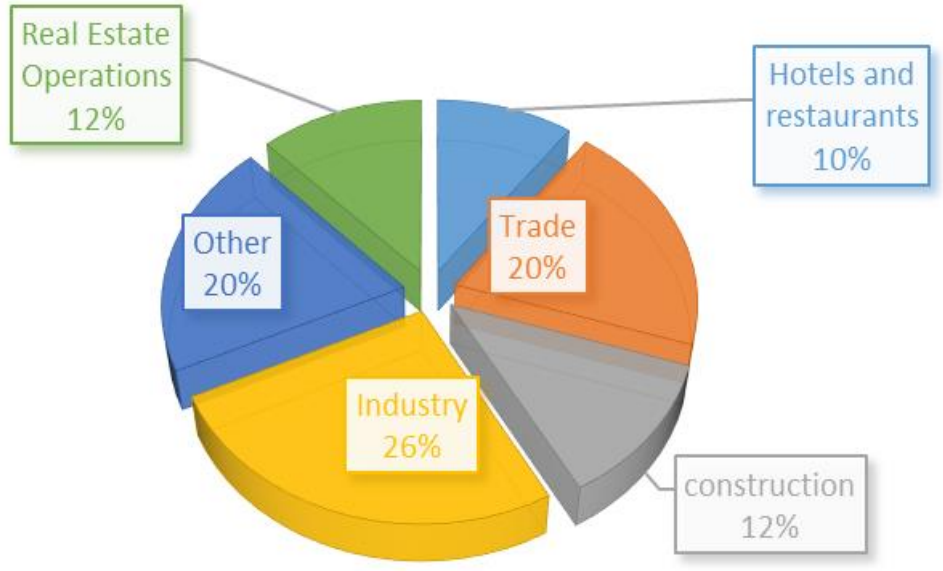

Source: Statistics of National Bank of Georgia 
the state budget of Georgia for 2020, economic growth was estimated at $4.5-5 \%$ (The 2020 Finance Act). By adding these both parameters, the economy of Georgia will shrink by $10-$ $10.5 \%$ in 2020 compared to the planned rate.

15 commercial banks operating in Georgia incurred a total loss of 747 million GEL in the first quarter of 2020, while the operating profit of the banking sector amounted to 386 million GEL. It is noteworthy that according to data of only March 2020, bank losses amounted to 943,130 million GEL. Loss is mainly due to the creation of reserve for neutralizing negative expectations from the COVID19 pandemic (NBG, Statistics 2020). In particular, the banking sector, as of March, created reserve for possible loan losses of 1.2 billion GEL to take out insurance against risk of potential losses.

\section{The anti-crisis plan}

It is important for the Government of Georgia to bear in mind that the key task during the Coronomic crisis is to overcome the epidemic while minimizing the damage to the national economy. As for the post-crisis period, it requires a special program to stimulate economic revival which will have to be done separately (Papava V., Charaia V., 2020: 9)

In the anti-crisis plan of the state we can highlight two main directions: direct subsidies and tax incentives. The first of them provided 940 million GEL in financial assistance packages (See Table 2) and about half (49\%) of that on account of a compensatory allowance for loss of employment due to a pandemic and nearly one third $(27 \%)$ - on subsidies for preserving jobs (https://stopcov.ge/ka/Gegma).

The following tools have been developed within the payment delay mechanism:

- Deferment of loan service payments for 3 months;

- The deferral of income and property taxes in the tourism sector for 4 months;

- The deferral of customs clearances for car importers until 1 September.

\section{Conclusions and recommendations}

The general analysis of the current account shows that if in the short run we fail to replace foreign direct investment, remittances and tourism revenues with alternative cash flows, in addition to a significant risk of recession, the issue of national currency exchange rate stability is at stake.
The anti-crisis plan unequivocally repeats the trend, the problem contents of which we have already mentioned in the analysis of the structure of budget expenditures. The anti-crisis plan is fully focused on coping timely with social challenges and does not provide for economic stimulus and structural reforms.

According to figures released publicly by the government of Georgia, the country will get funding of $\$ 3$ billion this year, including $\$ 1.5$ billion from the banking sector and the remaining $\$ 1.5$ billion from the State. At present, sovereign debt of the State is 17.4 billion GEL. According to 2020 budget revenues, it was planned to attract 3 billion GEL as a loan. If we add these parameters, by the end of 2020, Georgiass sovereign debt will reach 25 billion GEL, which, based on projected shrinkage of the national economy, will be about $59 \%$ of GDP. As a result, in 2020, we will reach the $60 \%$-maximum that is set by the organic law of Georgia.

Fiscal policy needs to be substantially revised and structurally reformed. The degree of dependency of state budget revenues on sovereign debt provides a source of worry, while the share of subsidies and social direction in the structure of budget expenditures places severe pressures on the economy. It is necessary to implement the concept of "small government» within a short time frame. Otherwise, it is unclear from which source should be replenished the 2021 budget when sovereign debt is virtually off-limits to our country.

Although in terms of financial depth, there seems to be no signs of "overheating» in the banking sector, as they were observed during the financial crisis of 2008, worthy of note is loss recorded by the sector during the first quarter. Unlike the financial crisis of 2008, which was definitely caused by financial factors, the given economic reality was created by completely different (epidemiological) factors. Consequently, in this regard, it's too much of a risk to confine ourselves merely to making direct linkages between the parameters of financial depth. In addition to problem loans, another major challenge for the banking sector will be the lack of profitable investment projects, without which the banking sector will not be able to balance the risks posed by problem loans. In this context, it is important to re-evaluate the conceptual attitudes of the State towards the management and ownership of "strategic» facilities and state-owned enterprises, whose investment attractiveness is inelastic with respect to economic shocks.

Table 2. Financial structure of the anti-crisis plan

\begin{tabular}{lrr}
\hline & $\mathrm{mln}$ Gel & \multicolumn{1}{c}{$\%$} \\
\hline \hline bills subsidies & 120.0 & $13 \%$ \\
Small hotel loans subsidies & 10.0 & $1 \%$ \\
Compensation for job loss & 460.0 & $49 \%$ \\
Compensation for self-employed & 75.0 & $8 \%$ \\
Job maintenance subsidy & 250.0 & $27 \%$ \\
Additional social assistance & 25.0 & $3 \%$ \\
\hline
\end{tabular}




\section{REFERENCES}

Constitution of Georgia, Law of Economic Freedom;

European reconstruction and development bank (EBRD) 2020, https://www.ebrd.com/news/2020/ebrd-economies-seencontracting-by-35-per-cent-in-2020-48-per-cent-rebound-in-2021.html

Government of Georgia https://stopcov.ge/ka/Gegma

Kaufman, M., \& Leigh D. - Global Imbalances and the COVID-19 Crisis. https://blogs.imf.org/2020/08/04/global-imbalancesand-the-covid-19-crisis/

Krugman, P. - Notes on the Coronacoma (Wonkish), nytimes opinion, https://www.nytimes.com/2020/04/01/opinion/noteson-the-coronacoma-wonkish.html

Ministry of Finance of Georgia. https://mof.ge/saxelmwifo_vali;

National bank of Georgia - Statistical dates 2020, https://www.nbg.gov.ge/index.php?m=304;

Papava, V., \& Charaia, V., (2020). Coronomic crisis and some challenges for the Georgian economy. Georgian Foundation for Strategic and International Studies. Available at https://www.gfsis.org/files/library/opinion-papers/136-expert-opinioneng.pdf

Papava, V., (2020). Features of the Economic Crisis Under the COVID-19 Pandemic and the Threat of the Zombie-ing of the Economy. BULLETIN OF THE GEORGIAN NATIONAL ACADEMY OF SCIENCES, vol. 14, no. 3, 2020. http://science.org.ge/ bnas/vol-14-3.html

Stiglitz, J., (2020). - Conquering the Great Divide, Journal "FINANCE \& DEVELOPMENT". https://www.imf.org/external/pubs/ $\mathrm{ft} / \mathrm{fandd} / 2020 / 09 / p d f / C O V I D 19-a n d-g l o b a l-i n e q u a l i t y-j o s e p h-s t i g l i t z . p d f$

State Budget of Georgia 2020;

TBC Capital, COVID-19 Influence on Georgian Economic 14.5.2020

XE.COM, https://www.xe.com/currencycharts/?from=USD\&to=GEL\&view=1M 